\title{
Analysis on the Introduction of Greek Mythology in College English Teaching
}

\author{
Xinhui Fu \\ Foreign Language Department \\ Jilin Institute of Chemical Technology \\ Jilin, China
}

\begin{abstract}
As the origin of Western literature and art, Greek mythology has brought profound influence to humankind in terms of thought, philosophy, literature, values and language use. This paper analyzes the deep and profound influence of Greek mythology on college English vocabulary teaching, pragmatic teaching and cultural teaching from three aspects, thus confirms the necessity of cultural introduction in college English teaching.
\end{abstract}

Keywords-Greek mythology; college English teaching; cultural introduction

\section{INTRODUCTION}

In the process of college English teaching, one nonlinguistic knowledge factor that plays a significant role in improving English communication ability is often overlooked English cultural background knowledge. Language is used to communicate, which cannot only stress the correctness of words and sentences, whether the use of language is appropriate is more important. In specific context, it is necessary to respect the different national cultural characteristics of the two sides of the communication, and to identify the communication principles and patterns of each other and to make the language expressed psychologically be acceptable. When using the target language to communicate, in addition to the knowledge of the target language itself, such as pronunciation, vocabulary and grammar, it is also necessary to fully recognize the communication barriers caused by cultural differences, which will directly affect the proper and appropriate expression and use of language and cause exchange interruptions and failures.

Greek culture is the source of European culture. The guiding ideology of the famous Renaissance in European history is to return to ancient Greek culture. As the greatest achievement of Greek culture, Greek mythology has a supreme position in the history of the West and even the entire human history. Greek mythology is the origin of the world's cultural heritage and western literature and art. It has brought profound and far-reaching influence on human thought, philosophy, literature, values and language use. Therefore, in college English teaching, all aspects of vocabulary, etymology, phonetics, morphology and cultural studies should focus on the cultural introduction of Greek mythology. The purpose of this paper is to emphasize the method and importance of the penetration of English cultural background knowledge by explaining the important influence of Greek mythology on English language.

\section{THE INFLUENCE OF GREEK MYTHOLOGY ON COLLEGE ENGLISH VOCABULARY TEACHING}

Ancient Greece was the birthplace of European literature. As a product of the slave society, the main achievement of Greek early literature was mythology. Greek mythology are the intricate, imaginary, rich and colorful stories of gods and legends of heroes which were made up by ancient Greeks taking the major pedigrees of the god Zeus on the Olympus mountain in northern Greece and the surrounding male and female gods as the basis and combining the ancient Greek society's history and legends. Greek mythology is the most complete and abundant mythological collections in the mythology of the world, including the epoch-making, the birth of God, the genealogy of God, the change of the heavens, the origin of mankind and the the daily activities of Gods. In modern English, many words come from the names of the gods in Greek and Roman mythology, which are still playing an important role. The typical etymology are: Flora-the god of flowers in ancient Greek and Roman mythology. She married Zephy and her husband gave her a garden which is full of exotic flowers. In the spring, they walked in the garden with their hands and hands, and there were full of blooming flowers where they passed. Therefore, Flora refers to "plants" in modern English and derives the words, such as flower, flour, flourish, florist, etc.

It can be seen that college English teaching is not a simple language teaching, but also requires an in-depth understanding and analysis of English language and culture. It also discusses and analyzes the history and formation of language so that students can use language and understand language reasonably and appropriately.

\section{THE INFLUENCE OF GREEK MYTHOLOGY ON COLLEGE ENGLISH CULTURE TEACHING}

Greek mythology does not only affect the use and formation of English language, it also provides concepts and models, which has a subtle influence on the trend and value orientation of literary development. The adventurous spirits of God and men in Greek mythology, the overflowing passion of life, and those powerful, fluid, young and unrestrained forces, 
extraordinary wisdom, advocating personal honor, affirming personal values and dignity, etc. are all shown in mythical gods and heroes. And this is also the unique charm of Greek mythology which is different from other myths.

The personal values, modes of thinking, social outlook on life and cultural deposits formed in mythology have all served as foundation and source for the formation and evolution of later English language. Therefore, in addition to certain knowledge of language and literature, English learners should also understand Greek and Roman mythology, which will undoubtedly greatly help to increase interest in learning, expand vocabulary and understand some of the origins of Western culture.

\section{The INFLuence of GREeK Mythology ON COLLEGE ENGLISH PRAGMATIC TEACHING}

The purpose of cultural teaching is not simply to impart cultural knowledge, but to fundamentally improve the intercultural communicative competence of foreign language learners, to strengthen the main aspects of intercultural communication microscopically, to strengthen cultural influence, and to establish a cultural cognitive schema. As the source of Western traditional culture, Greek mythology embodied the ancient Greek people's concepts of survival, values and the society, which has a huge and long-lasting impact on the language formation of later generations. Therefore, to use the language reasonably and understand the habits and conventions of language use, it is inevitable to understand the origin and soil of English language that is Greek mythology. Chinese foreign language learners must consciously learn and accumulate to form certain cultural deposits. With the richness and systematicness of cultural knowledge, a target language cultural cognition schema is established so that fluent, appropriate language can be used. Many English idioms originate from Greek mythology.

The allusions in Greek mythology constitute a large component of the use of English language. The personal values, modes of thinking, social outlook on life and cultural deposits formed in mythology have all served as foundation and source for the formation and evolution of later English language. Therefore, in addition to certain knowledge of language and literature, English learners should also understand Greek and Roman mythology, which will undoubtedly greatly help to increase interest in learning, expand vocabulary and understand some of the origins of Western culture.

\section{To Use Greek Mythology to Penetrate Cultural BACKGROUND KNOWLEDGE}

In English teaching, the instillation of language knowledge is important, but for the college students who already have the basic knowledge, it is important to help them to understand the cultural factors of different countries and societies and make it faster and more effective for them to master the language they are learning. In order to better penetrate culture in language teaching, from the perspective of Greek mythology's influence on English culture which is mentioned above, the author believes that the following aspects should be taken into consideration:
Firstly, infiltration of cultural knowledge in teaching: the cultural infiltration should be reflected in all aspects of teaching, making students to accept English countries' social and cultural background knowledge in a subtle manner, to understand the various customs in people's lives and interactions, and to know how to associate with people, what festivals are more important to the people in English-speaking countries and how do these festivals are celebrated.

Next, foreign teachers' diversified teaching methods: with the rapid development of digitization and networking, modern English teachers can no longer be confined to the teaching mode of a single teaching material, but should closely follow the times, grasp the characteristics of modern students and guide them in a targeted manner.

\section{CONCLUSION}

In summary, we can clearly recognize that Greek mythology affects all aspects of English culture and it is also the inspiration source of many British and American writers. It influences and enriches English culture and is the indispensable cultural background knowledge for English learners. Therefore, college English teachers should pay attention to the introduction of the cultural background knowledge of Englishspeaking countries and properly infiltrate Greek mythology in teaching, so as to increase students' sensitivity to cultural differences and flexibility in handling cultural differences, in order to improve English teaching efficiency, which will improve students' ability to communicate in English and inspire students' interests in language learning, as well as broaden their knowledge.

\section{REFERENCES}

[1] Wang Ting. A Restricted View on the Influence of Greek Mythology on Western Values[J]. College English (Academic Edition), 2011(2).

[2] Wei Zhaoxi. Exploration and Practice of College English Cultural Theme Teaching[M]. Beijing: China Agricultural Science and Technology Press, 2010.

[3] Zhu Jiake. Cultural Teaching in College English Teaching[M]. Wuhan: Huazhong University of Science and Technology Press, 2009.

[4] Hu Wenzhong. On Intercultural Communication Research. Language and Writing Applications, 1992(3).

[5] Zhu Xiaoyun. English Vocabulary from Greek and Roman Mythology. Journal of Chengdu University (Social Science Edition), 2007, (3).

[6] Helder. On Greek Art [A]. Liu Xiaofeng. The Aesthetic Spirit in Human Dilemma - Selections of Philosophers and Poets on Aesthetic[C]. Shanghai: Oriental Publishing Center, 1996.

[7] Chen Li, et al. The Important Position of Greek Mythology as English Background Knowledge[J]. Journal of Zhongzhou University, 2003, (1). 